\title{
THE CHALLENGES OF JOURNALISM IN THE REPUBLIC OF MACEDONIA DURING THE COVID-19 PANDEMIC
}

\author{
Eleonora SERAFIMOVSKA
}

$\mathrm{PhD}$, Ss. Cyril and Methodius University in Skopje Institute for Sociological, Political and Juridical Research

E-mail: eleonora@isppi.ukim.edu.mk

\section{Marijana MARKOVIKJ}

$\mathrm{PhD}$, Ss. Cyril and Methodius University in Skopje Institute for Sociological, Political and Juridical Research

E-mail: marijana@isppi.ukim.edu.mk

\section{Tea KONESKA-VASILEVSKA}

MSc, Ss. Cyril and Methodius University in Skopje Institute for Sociological, Political and Juridical Research

E-mail: tea.k@isppi.ukim.edu.mk

\begin{abstract}
The pandemic caused by COVID-19 has led to serious changes in the lives of citizens. In a time of restricted mobility, people had to rely on media news and information to help them understand the COVID-19 crisis, hear the latest information on the extent of the spread of the disease, and learn how they can protect themselves and their families. In conditions when the media become a single window to reality and events, the role of journalists is especially important, as in any crisis situation. Hence the research interest is on difficulties faced by journalists in carrying out their mission. The research question was defined as: "What are the challenges of journalism in the Republic of Macedonia during the pandemic? What did journalists actually face in the process of providing timely information to the public?" The definition of the research problem was aimed at examining how the pandemic affected journalism in terms of the safety of journalists' physical and mental health, changing working conditions, use of information sources, exposure to pressures and influences from various factors and / or institutions. The ongoing research aims to test the
\end{abstract}


assumptions that journalists and media professionals in the country work in unpredictable, stressful and difficult conditions related to their physical and mental health, amid increased pressure from state authorities in the pandemic reporting process, as well as an increasing amount of misinformation, fake news and hate speech.

Keywords: journalism, media, pandemic with COVID-19, Republic of Macedonia

\section{Introduction}

The COVID-19 pandemic that spread across the world at the start of 2020 posed a serious threat to the life and health and future of everyone. Responsible parties in the countries across the world have worked tirelessly to prevent the epidemic and alleviating its impact. The fact is that almost every aspect of human life known until now has changed due to this "plague" of the $21^{\text {st }}$ century; therefore, finding an effective response to the pandemic has become a top priority to all decision-makers across the world. In addition to the emergency measures related to health, other activities for neutralising the societal, economic, labour, cultural and safety impact from the crisis have been enforced_Mitigating a global health crisis while maintaining freedom of expression and information, n.d.). Humanity entered a crisis that does not seem to end, and the reasons for its emergence or the forces that enable it, as well as the measures that can put it fully under control, are not entirely familiar.

In the case of a pandemic of such vast proportions where social distancing among people was promoted in order to protect lives, and self-isolation is seen as a sign of communal responsibility, billions of people could hardly wait to receive information about what type of disease it was and how they could protect themselves and others from this mysterious illness.

Soon after proclaiming the pandemic, there was a rapid spread of topics and information related to COVID-19 that literally flooded the media. There were truths, half-truths, lies, fact-checked and unchecked information emerging every minute. It soon became clear that the world was facing yet another, parallel pandemic of disinformation known as "an infodemic"1. The World Health Organisation revealed that the emergence of COVID-19 and its subsequent protective measures were accompanied by a vast array of information which made it difficult to find secure sources and guidelines. "The Coronavirus disease (COVID-19) is the first pandemic in history in which technology and social media are being used on a massive scale to keep people

\footnotetext{
${ }^{1}$ Infodemic is a combination of "information" and "epidemic" that usually relates to the fast and far-reaching spread of accurate and inaccurate information about something, such as a disease. The term infodemic was first coined in 2003 and has been frequently used during the COVID-19 crisis (Infodemic, n.d.).
} 
safe, informed, productive and connected. At the same time, the technology we rely on to keep connected and informed is enabling and amplifying an infodemic that continues to undermine the global response and jeopardizes measures to control the pandemic", states the joint statement by WHO, UN, UNICEF, UNDP, UNESCO, UNAIDS, ITU, UN Global Pulse and IFRC ${ }^{2}$ (World Health Organization, 2020).

Although journalism has been considered a stressful and risky profession already, it quickly climbed to the top of the most stressful and risky professions in the current circumstances. Journalists were faced with a series of requests and expectations for accurate, fact-checked, timely, unbiased, calming, ethical, and responsible as well as free and transparent reporting. In what circumstances did journalists find themselves, how prepared they were to enter this crisis and report on it while following all professional standards, what problems and challenges did they face during their day-to-day work, how much did they suffer (both physically and mentally)? These questions became an interesting research topic globally.

\subsection{Communication ecology}

The COVID-19 pandemic, alongside the infodemic, that marked 2020 and seriously impacted 2021, the realisation that it made an impact on public behaviour and continues to do so and the fact that all this media noise resulted in a spread of fear and panic among the entire global population, inevitably brought the conceptual model of communication ecology at the forefront of all media and communication research projects. On a broad level, the term communication ecology relates to the context, the environment in which communication processes first appear and continue happening (Hearn \& Foth, 2007).

This model is used successfully in circumstances of a need to analyse and present complex relationships between social interactions, discourse and communication media and technology of individuals, collectives and networks in physical and digital environments. These processes include people who communicate face to face and with a mix of communication and media technologies (Tacchi, Slater \& Hearn, 2003).

The ecological communication model is a modern model that enables researchers a holistic approach of understanding the dynamically interconnected links between social dimensions, discourse and communication technology both in the physical and digital environment. The use of ecological metaphor significantly extends the potential sphere of researching communications and media. In fact, this model turns the attention from studies directed at single communication devices or applications towards interactions among the entire ecosystem. Therefore, it broadens the opportunity for research and understanding of those changes that happen in the public space, that is, to the population.

\footnotetext{
2 Joint statement by WHO, UN, UNICEF, UNDP, UNESCO, UNAIDS, ITU, UN Global Pulse, and IFRC.
} 


\subsection{Communication ecologies during public health crises and challenges posed to journalism}

The theory of dependence on media indicates that during a public crisis, the individual use of media resources increases due to the expanded need for information in order to gain an understanding about the unstable situation (BallRokeach, 1985). The public health emergency is one example of a collective event that can raise the dependency and use of communication resources. The increased threat and uncertainty as a result of the newly emerged disease will most likely motivate individuals to construct a specific communication ecology in order to find information about the disease. The case of COVID-19 is a new example of the communication ecology, because although it is presented as a local, joint (micro) crisis (given that COVID-19 impacts local communities), it also garners significant national and international (macro) media coverage as a global pandemic (Houston, Thorson, Kim \& Mantrala, 2021).

Nevertheless, this only emphasises the aspect of publicity in the communication ecology. However, this research project does not focus on the public and its need for more information; instead, it attempts to shine a light on the aspect and position of journalists in this complex, communication network called communication ecology, their role and influences.

The biggest challenge for journalists during the COVID-19 pandemic is to collect and distribute accurate information. As a norm, the journalist's role is to share information with the public, and this becomes especially important during public health emergencies, such as the COVID-19 pandemic (Perreault \& Perreault, 2021).

Journalists exist as part of the ecology in which their work has an impact and is influenced by its surroundings. Journalist organisations are usually part of the ecological communication, which means that during the COVID-19 pandemic, journalists and journalist organisations have been working in a specific "communication ecology COVID-19". Journalists serve as a resource to others in the frames of the ecology, simultaneously balancing their personal challenges with the global crisis.

According to a journalist residing in Wisconsin, interviewed in November 2020 for a study that investigated the discursive construction of journalism during the COVID-19 crisis, to be a journalist during COVID-19 means "to pursue the truth and promote critical thinking and to try and teach others about the importance of these things" (Perreault \& Perreault, 2021).

By taking this ecological approach, the authors of the abovementioned study emphasise the multi-layered nature of the journey for the journalists during the pandemic, from the personal vulnerability and fear they have suffered to the path of undergoing changes in the way of managing their sources and increased arguments in the fight against disinformation. In some way, this jeopardized the journalists' capacity to fulfil their duties to their respective communities (Caliphate shows us what performative transparency conceals, 2021). 


\section{Referential research}

In research conducted by Reuters Institute for the Study of Journalism and Toronto University, journalists were asked a series of questions about their work, mental health and other problems they are facing in June 2020, at a time when all countries were in some way impacted by COVID-19. According to the results of this research, carried out on a sample of 73 journalists from international media organisations with a response rate of $63 \%$, the majority of respondents, around $70 \%$, replied they were suffering from some level of psychological stress, and 26\% reported clinically increased anxiety, including symptoms of worries, tension, insomnia, lack of focus and tiredness. Also, around $11 \%$ of respondents reported significant symptoms of a posttraumatic stress syndrome, including forced flashbacks of traumatic events related to COVID-19, a desire to avoid remembering these events and feelings of guilt, fear, anger, disaster and shame (COVID-19 is hurting journalists' mental health, 2020).

This was a sample of experienced reporters who worked in already established media, with an average of 18 years of work experience and all of them (99\%) considered themselves to be in good physical health but still got seriously hit by the circumstances. The situation can be even worse in "less privileged" parts of the journalistic profession.

The research project entitled "Journalism and the pandemic: Global overview of its impact", conducted within the frameworks of a research initiative by the International Center for Journalists (ICFJ) and the Center for Digital Journalism of Columbia University started in April 2020 aimed at investigating the impact of the coronavirus crisis upon global journalism (Posetti, Bell \& Brown, 2020).

This vast research included 1,406 respondents (journalists, editors and other media workers) from 125 countries worldwide. The primary research results point to some frightening information, such as the fact that " $70 \%$ of respondents judged the psychological and emotional impact from dealing with the COVID19 crisis as the hardest aspect of their job, and 82\% reported at least one negative emotional or psychological reaction as a result of the pandemic" or the result that " $20 \%$ of the respondents who are journalists said that their experience with abuse, harassment, threats or attacks online is much worse than usual".

In reference to disinformation, the results from the study are also serious because they indicate that "politicians were identified as a top source of disinformation from the $46 \%$ of respondents". Two thirds of respondents identified Facebook as "a fertile vector of disinformation". On the overstepping of freedom of speech " $48 \%$ of respondents reported that their sources expressed fear from retaliation for having spoken to journalists in regard to COVID-19". 
There is other research that also has journalism during the pandemic as focus of interest. Research by BIRN (Balkan Investigative Reporting Network) on the working conditions of journalists from the Balkans since the start of the COVID-19 pandemic (More work, less pay: COVID-19 worsens plight of stressed-out Balkan reporters, 2020) analysed the following aspects of work by journalists: finances, scope of work, mental health and access to information. Between mid-April and mid-May last year, BIRN surveyed media workers from Serbia, Albania, Bosnia and Herzegovina, Montenegro and North Macedonia, asking them how the COVID-19 pandemic changed their life and work, with focus on financial issues, their scope of work, problems with mental health and collaboration with public officials. The data from these four aspects show that the majority of media workers are scared for their living standard, with almost two thirds highly ranked financial support as a serious necessity. The situation seems to have been most difficult in Macedonia. Further, more than 58\% replied that reporting on the COVID-19 had an impact on their mental health. Most journalists reported having the support of their employers when it comes to sick leave and receiving appropriate protective equipment, and around $40 \%$ replied that the rate to which public officials had not answered their questions had increased during the pandemic.

\section{Research methodology}

To provide an answer to the primary research topic, this project carried out an online survey of journalists and other media workers, as well as desk research, with both of the primary and secondary data being analysed.

\subsection{Desk research (secondary data)}

In this part of the research, the emphasis was on searching, consulting and analysing texts, and press articles published in Macedonian that treat the topic of journalism and media during the COVID-19 pandemic, in various media.

Measurement of analysis was a single press article, a single text or a single publication with the keywords: journalism, journalists, COVID-19 pandemic. Some of the texts convey analyses of the situation not only in Macedonia, but also comparative analysis and data.

A criterion for approaching the sample of analysis was treating journalism and Macedonian media during the pandemic, regardless of whether the journalists/media workers/experts talk about themselves or someone else is doing the talking/research on the challenges of journalism and the media in general since the beginning of the COVID-19 pandemic.

Nine units were analysed overall. Out of these, six were press articles/opinions by experts, and three were publications. 
All measurements of analysis were classified according to a few primary parameters: type of unit of analysis, subject of analysis and/or source of information, main topic and challenges of the journalists mentioned in the text (the primary subject of research).

The table below provides a description of all analysed units according to the first three parameters, and the subsequent table lists all challenges that journalists were faced with which were either recognised by themselves or other experts. The first table also has links to where the units of analysis were published as well as the time of publication.

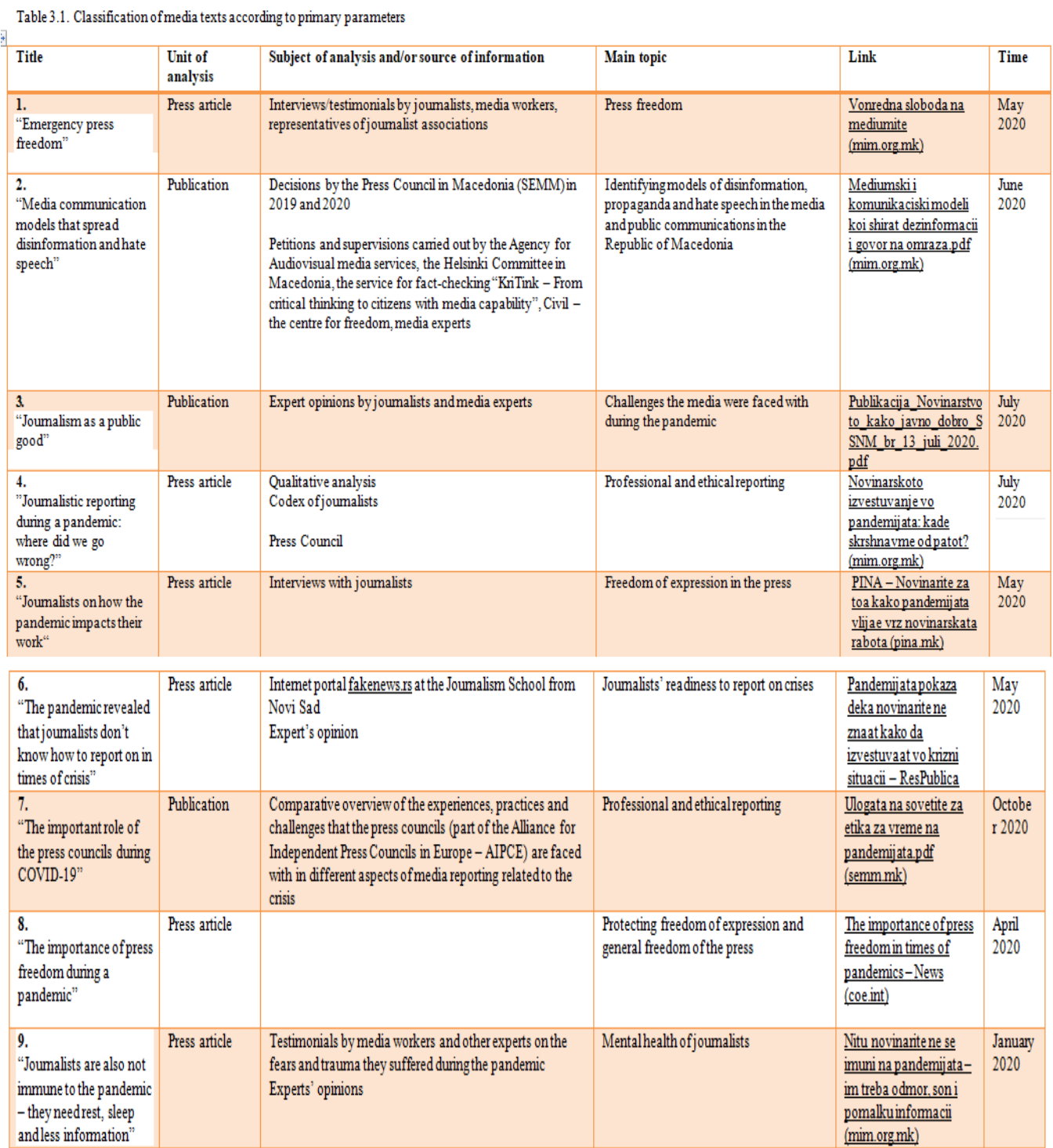


Eleonora SERAFIMOVSKA, Marijana MARKOVIKJ, Tea KONESKAVASILEVSKA

\begin{tabular}{|c|c|}
\hline $\begin{array}{l}\text { l. } \\
\text { "Emergency press freedom" }\end{array}$ & Joumalists' exposure to trauma that causes long-tem stress, exhaustion, anxiety, fear. \\
\hline $\begin{array}{l}\text { "Media communicationmodels that } \\
\text { spread disinformation and hate } \\
\text { speech" }\end{array}$ & $\begin{array}{l}\text { The press became a transmitter of messages because the Govemment and health institutions closed their doors to joumalists; } \\
\text { Joumalism tumed into public relations; } \\
\text { Institutionallack of transparency towards the press; } \\
\text { Joumalists are accused of sensationalist reporting; } \\
\text { Joumalists are accused of sprea ding fakenews; } \\
\text { Noncritical distribution of information without previous fact-checking; } \\
\text { Online communication between public officials and joumalists that doesn't leave space for asking questions. }\end{array}$ \\
\hline $\begin{array}{l}3 . \\
\text { "Joumalism as a public good" }\end{array}$ & $\begin{array}{l}\text { Media models, groups of media andindividuals that spread disinformation, propaganda and hate speech, dominant in the online space; } \\
\text { Online media are the most frequent infingers of professional standards; } \\
\text { Intemet media are an especially suitable channel for spreading disinformation and encouraging hate speech. }\end{array}$ \\
\hline $\begin{array}{l}4 . \\
\text { "Joumalistic reporting during a } \\
\text { pandemic: where did we go wrong?" }\end{array}$ & $\begin{array}{l}\text { The media are going through an economic crisis; } \\
\text { The pandemic showed us that local news is more important than ever; } \\
\text { A need for new business models in joumalism; } \\
\text { Infingement of press freedom; } \\
\text { Ethical questions when reporting on deaths; } \\
\text { Silencing the media; } \\
\text { Rough censure, both online and offline. }\end{array}$ \\
\hline $\begin{array}{l}5 . \\
\text { "Joumalists on how the pandemic } \\
\text { impacts their work" }\end{array}$ & $\begin{array}{l}\text { Some media became a tool for spreading half-truths, lies and disinformation; } \\
\text { Unprofessional and unethical reporting; } \\
\text { Self-regulation as its own reporting practice. }\end{array}$ \\
\hline $\begin{array}{l}6 . \\
\text { "The pandemic revealed that } \\
\text { joumalists don't know how to report } \\
\text { on in times of crisis" }\end{array}$ & $\begin{array}{l}\text { The economic consequences from the crisis are already felt, and according to our estimates, in the coming peniod these will be felt evenmore by } \\
\text { joumalists and media workers; } \\
\text { Infingement to the freedom of expression; } \\
\text { Influx of fake news which joumalists are responsible to uncover for what they are. }\end{array}$ \\
\hline $\begin{array}{l}7 . \\
\text { "The important role of the press } \\
\text { councils during COVID-19" }\end{array}$ & $\begin{array}{l}\text { The media are not ready to report in times of crisis; } \\
\text { Lack of education amongjoumalists on how to report during a crisis; } \\
\text { An incredible volume of fake news. }\end{array}$ \\
\hline $\begin{array}{l}8 . \\
\text { "The importance of press freedom } \\
\text { during a pandemic" }\end{array}$ & $\begin{array}{l}\text { Sensationalist media reporting; } \\
\text { Insufficient protection of privacy and personal data by joumalists; } \\
\text { Hindered access to information. }\end{array}$ \\
\hline $\begin{array}{l}\text { "Joumalists are also not immune to the } \\
\text { pandemic-they need rest, sleep and } \\
\text { less information" }\end{array}$ & The most senious threats to joumalism and joumalists. \\
\hline
\end{tabular}

\subsection{Online survey (primary data)}

This research has been initiated by the Global Risk Journalism Hub, an informal network of leading scientists in journalism ${ }^{3}$, and was conducted and analysed as a research project entitled "Journalism and media during a pandemic", within the project "Political, juridical and cultural challenges in dealing with the pandemic", carried out by the Institute for Sociological, Political and Juridical Research, at the University Ss. Cyril and Methodius in Skopje.

The Global Risk Journalism Hub (GRJH) joins researchers, educators and practitioners from all over the world, with the aim of studying the ways of reporting on events related to global crises.

Journalists from across the world are equally challenged when it comes to global "risks", such as health pandemics, ecological crises and humanitarian conflicts. In this sense, "risk journalism" emphasises the way in which journalists from different regions join these global topics. We live and act in a world in which journalists are facing big data, new actors and disinformation; therefore, it is essential to examine current journalistic practices in order to set

\footnotetext{
${ }^{3}$ More info: https://www.globalriskjournalismhub.com/
} 
the foundations for developing new models of transnational reporting on global crises.

The aim of the Network is to initiate projects that overcome national borders and provide new space for dialogue and debate on what is the most appropriate way to improve the quality of journalism of public interest given the current dimensions of globalised ecosystems of digital data. The Project Lead is Professor Ingrid Volkmer from the University of Melbourne, Australia.

Republic of Macedonia has joined the network since the very beginnings of the international network of researchers being established.

The primary question of this research is: What are the challenges of journalism in the Republic of Macedonia during the COVID-19 pandemic?

Secondary questions are:

1. Do journalists recognise the importance of disinformation when it comes to risk?

2. What are the main sources of information during the COVID-19 pandemic?

3. What is the perception of journalists on the financial security of the press during the pandemic?

4. How much have they personally been exposed to the virus? Have the media they work for provided them with an appropriate education and equipment to be able to do their jobs professionally?

\subsubsection{Research instrument}

The survey consists of 34 questions of a closed type. The questionnaire is structured in a few areas: demographic variables, perception of risk of personal exposure to COVID-19, sources of data, barriers to reporting, disinformation, financial security of the press. The questionnaire was set up on the Google Forms platform. The link to the questionnaire was shared via email or Facebook Messenger. It was sent via an email to the Association of Journalists in Macedonia alongside a request to distribute the questionnaire to their members. Separate emails were sent to more than a hundred journalists via LinkedIn and other relevant editorial contacts with the press, TV, radio and Internet portals. Despite the large number of sent email messages, the questionnaire was filled by only 29 journalists, which is only $1 / 5$. The survey was carried out in March 2021.

\subsubsection{Sample}

The sample consisted of 29 journalists $(62.1 \%$ female and $7.9 \%$ male $)$. The largest percentage of respondents have the status "full-time employee" $(82.8 \%)$. Out of those, $51.7 \%$ are editors, and $41.4 \%$ are journalists. The biggest percentage of journalists have many years of relevant work experience $(69 \%$ of respondents have been employed by a medium for more than 10 years, $20.7 \%$ have between 5-10 years of relevant work experience, and none of the respondents is at an entry level position). Primary domain of reporting for $58.6 \%$ of respondents are the national media, whereas journalists reporting for 
local media and those who primarily cover international media are equally represented at $13.8 \%$. The respondents were primarily publishing online articles $(58.6 \%)$, whereas the press media and TV are covered in equal measure at $17.2 \%$.

\subsubsection{Research results}

Challenges journalists faced while reporting on topics related to COVID-19

Around 41.4\% were reporting on COVID-19 occasionally, 34.5\% were doing it frequently, and the remaining percentage is equally spread between the categories "never", "always" and "rarely" at $8 \%$ each.

Reporting about the pandemic was a challenge for $55.1 \%$ of respondents (24.1\% "fully agree" with this statement and 31\% "agree"), $34.5 \%$ have neutral opinions, and the remaining percentage do not agree with the statement.

In regard to the journalists' perception on their COVID-19 virus exposure, less than half (48.3\%) believe they were personally exposed to a risk of contagion (13.8\% were entirely certain that they agree with this statement and $34.5 \%$ agree with the statement to a lesser intensity), $44.8 \%$ did not agree with the given statement. The largest percentage of respondents indicated they knew at least one colleague who got the virus (93.1\%).

$72.4 \%$ of respondents agreed that the organisation they work for provided them with appropriate protective equipment, 20.7\% are neutral (neither agreed nor disagreed with the statement), and $6.9 \%$ of respondents do not agree with this statement. $69 \%$ of respondents received appropriate guidelines on how to protect themselves from the virus. Half of the respondents (51\%) received appropriate equipment for work from home, and $31 \%$ did not agree they have received appropriate equipment. 
The challenges of journalism in Republic of Macedonia...

Image 3.1. The media organisation provided an appropriate equipment for work from home

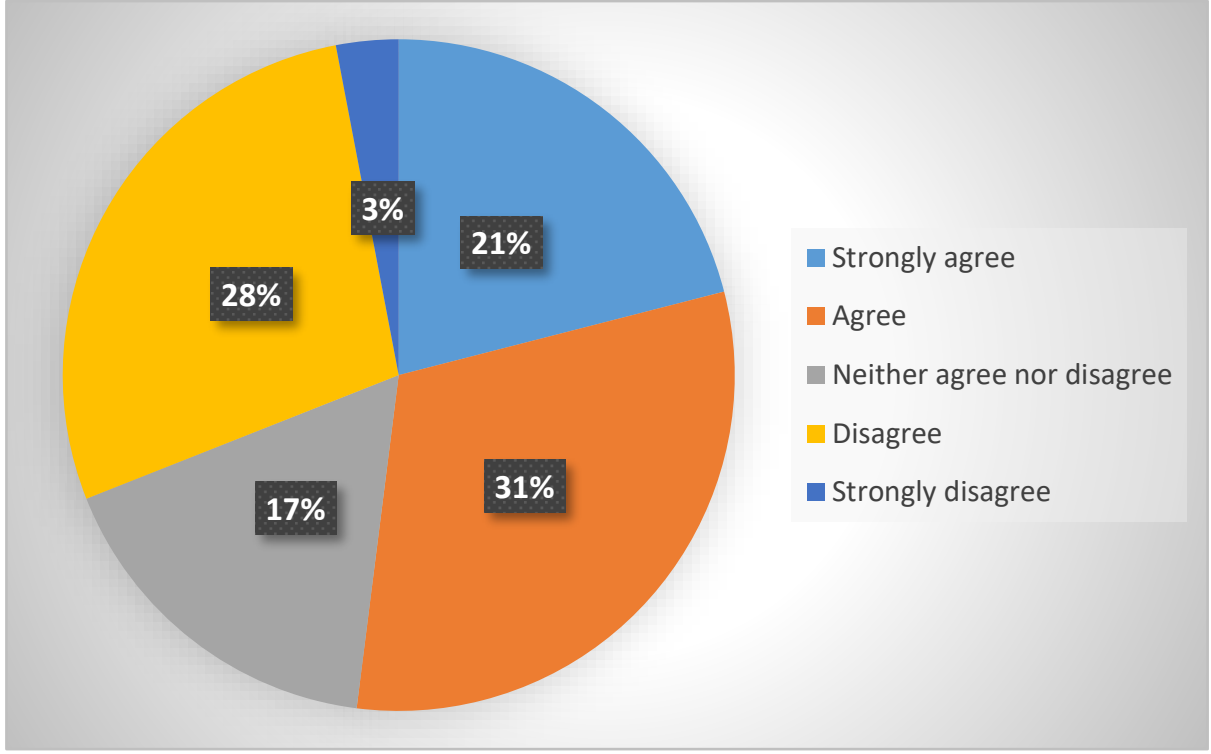

Image 3.2. Sources of data on COVID-19

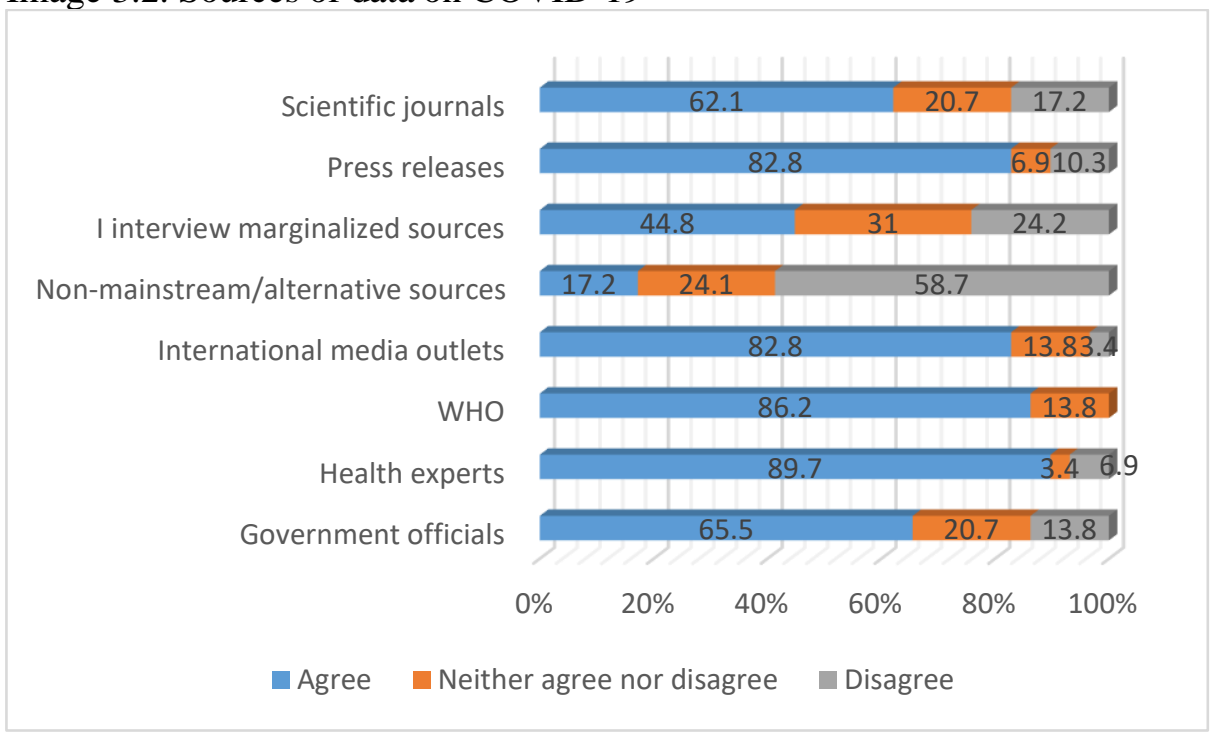

The next series of questions related to what contributes to the reporting on COVID-19 in the country or has some impact on it, at the same time being dependent on the experience of the journalist. 
Although the largest percentage of respondents were not exposed to any pressures from the Government, some percentage of them stated they were under Government pressure to publish a text $(8.7 \%)$, whereas a slightly larger percentage of respondents stated they were under pressure not to publish certain information.

Table 3.3. Exposure to Government pressures to publish or not publish a text

\begin{tabular}{|l|l|l|}
\hline Government pressure to publish & No & Yes \\
\hline To publish & $91.3 \%$ & $8.7 \%$ \\
\hline Not to publish & $86.2 \%$ & $13.8 \%$ \\
\hline
\end{tabular}

The largest percentage of respondents (72.4\%) were not exposed to any limitations when reporting on some aspect of the pandemic. Although to a large extent the respondents were not exposed to any pressures, they were still exposed to pressures of a religious $(20.7 \%)$ or a cultural $(24.1 \%)$ character.

Image 3.3. Type of pressures journalists were faced with when reporting on COVID-19

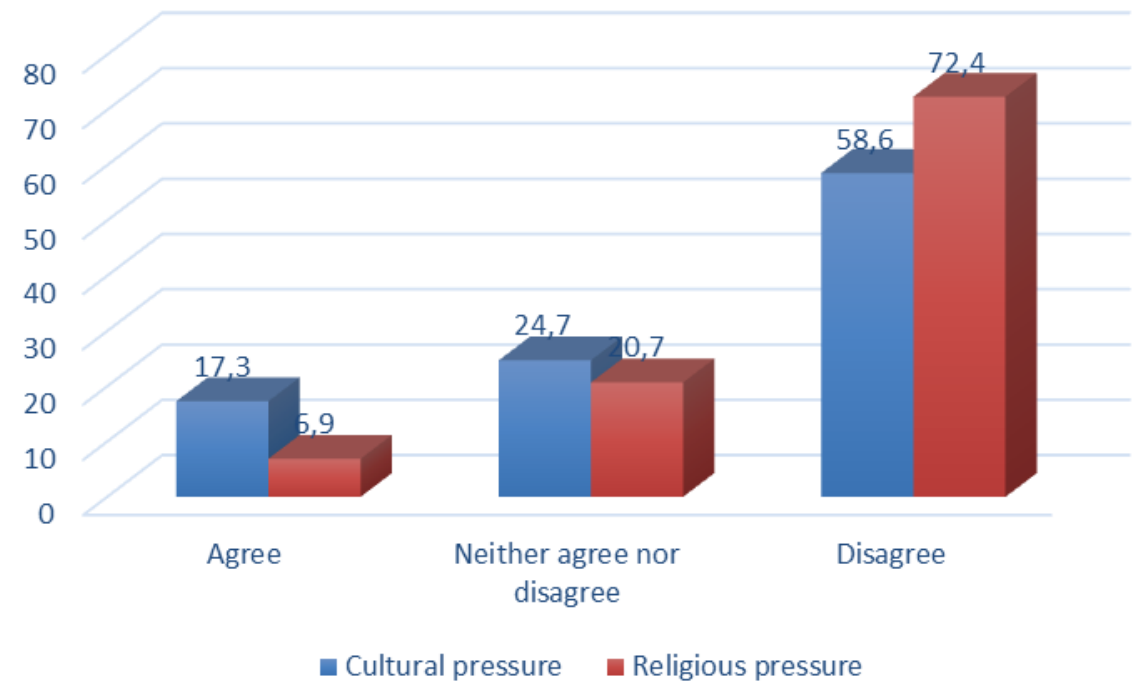

\subsubsection{Disinformation}

In this research, the term "disinformation" is meant to signify false information that intentionally, frequently and secretly gets spread in order to impact public opinion or cover up the truth. This explanation has been included in the questionnaire before relaying all the questions. 
The results show that all respondents are familiar with the meaning of the term disinformation. Half of the respondents $(51.7 \%)$ have received training on how to handle disinformation, $37.9 \%$ neither agreed nor disagreed that they have received training, and only $10.3 \%$ stated they have not received any training. According to $69 \%$ of respondents, the organisation they work for has guidelines on identifying disinformation.

Image 3.4. The media organisation has guidelines on identifying disinformation

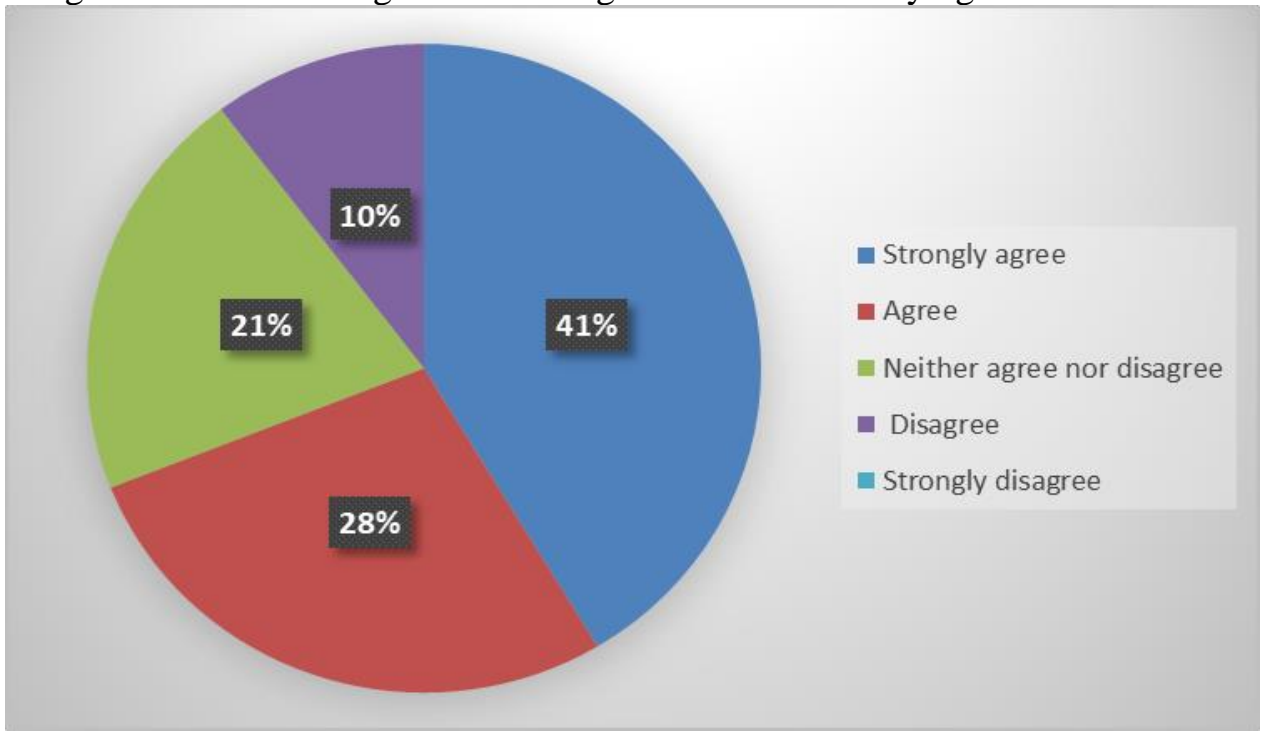

On whether disinformation influence the way in which they or their colleagues do their job, $65.5 \%$ of respondents stated yes.

Image 3.5. Disinformation has impact on the way journalists are reporting

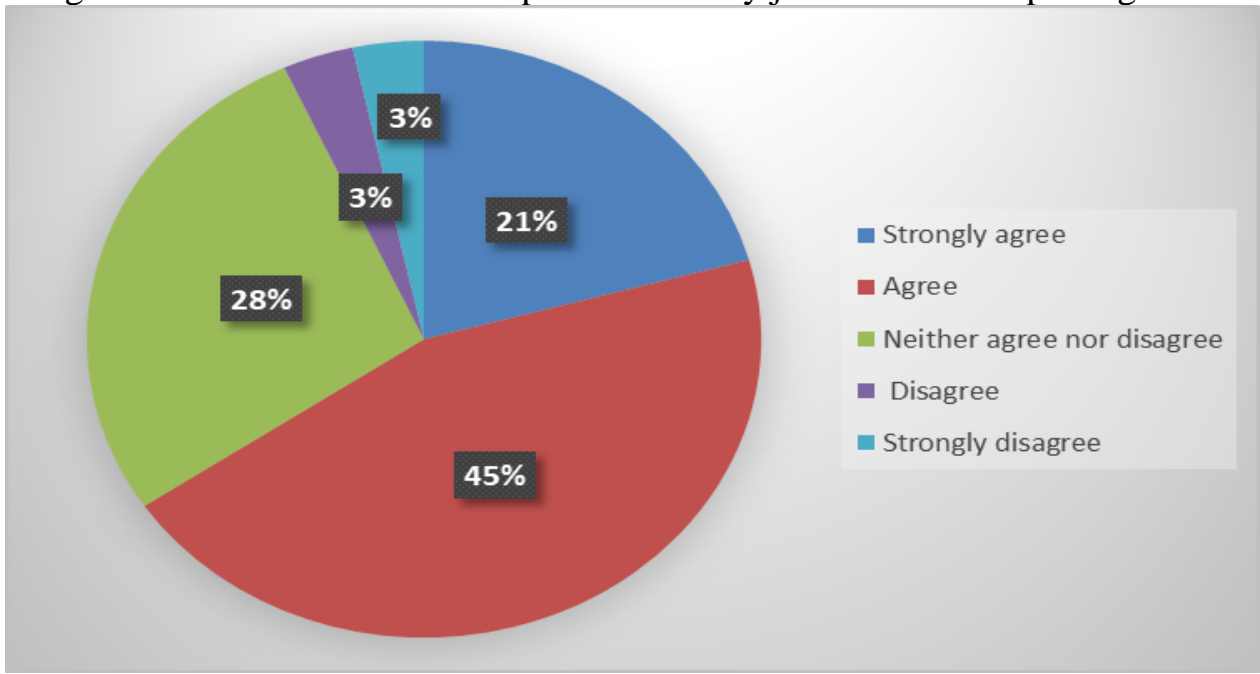


Image 3.6. The organisation the journalist works for is responsible for spreading disinformation

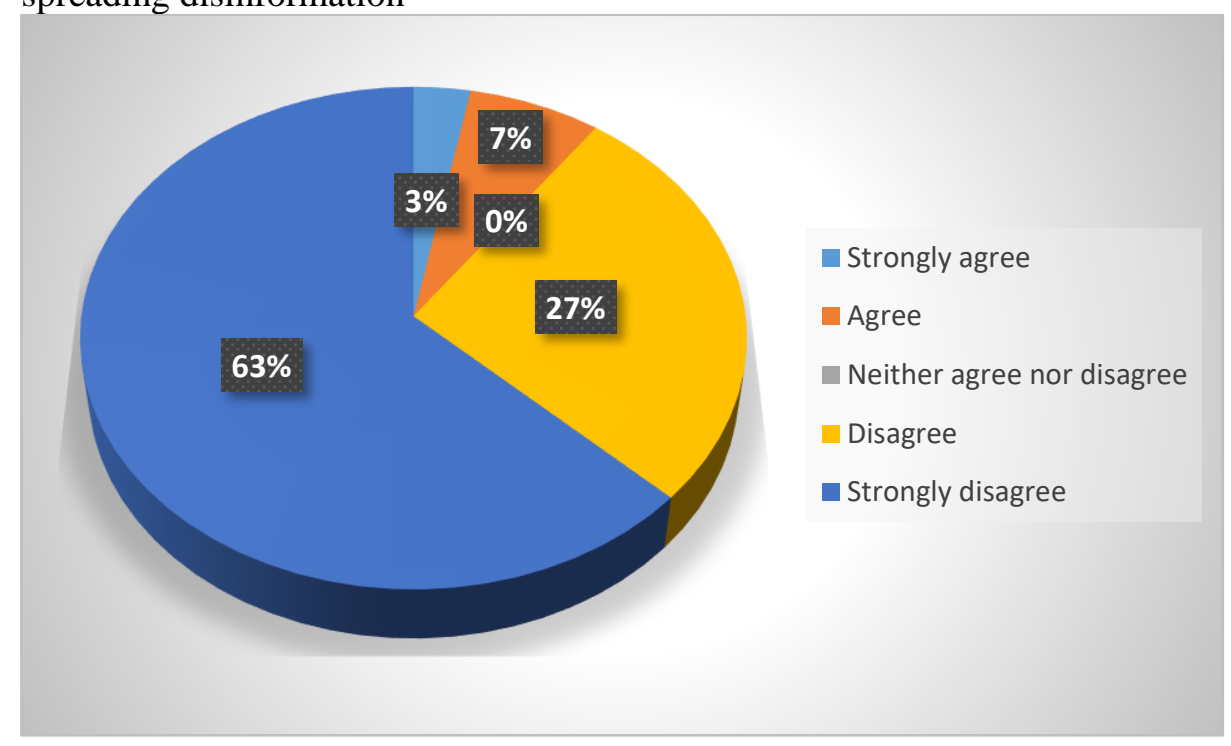

The largest percentage of respondents stated that the journalist organisation they work for was not responsible for spreading disinformation; however, $10.3 \%$ stated that the organisation they work was, in fact, responsible for spreading disinformation.

\subsubsection{Finances}

According to the answers of $58.6 \%$ of respondents, the media organisations that the journalists work for do provide the necessary budget and logistics for covering the pandemic, whereas $13.8 \%$ stated that the organisations they work do not provide the appropriate budget and logistics (27.6\% neither agreed nor disagreed with the statement).

The largest percentage (79\%) of respondents showed concerns and fear that the organisation they work for will be going through financial difficulties due to the pandemic. 


\section{Conclusion and discussion}

In order to study the impact from the COVID-19 pandemic on journalism, a research project was initiated in March 2021 within the framework of the Global Risk Journalism Hub, conducted by a research team from the Institute for Sociological, Political and Juridical Research as part of the larger project "Political, juridical and cultural challenges in dealing with the pandemic". Said research is the beginning of a more detailed study of journalistic reporting during a global crisis and had the task of providing an answer to the primary question: "What are / were the challenges of journalism in the Republic of Macedonia during the COVID-19 pandemic? What were journalists faced with in the process of securing timely information for the public?" This main research topic was further broken down into several questions: Do journalists recognise the importance of disinformation in conditions of risk? What are the primary sources of gathering data during the COVID-19 pandemic? What is the perception of journalists of the financial stability of the press during the pandemic? And how much were they personally exposed to the virus? Did the media organisations they work provide appropriate education and equipment for them to continue doing their jobs professionally?

The analysis of the primary and secondary data point to the fact that freedom of speech, the influx of disinformation, professional, responsible and ethical reporting, the readiness and level of education of journalists on reporting during crises, physical and mental health of journalists and other media workers, as well as the economic crisis, are the main themes, that is to say, the aspects of the COVID-19 communication ecology in Macedonia.

Shining a light on journalism and media as the main aspects of the communication ecology, it can be said that the top challenge for journalists in the Republic of Macedonia today is the infringement of their freedom of speech. In the few analysed media texts, there was a clear indication of "infringement on the freedom of press", "silencing the media", "rough censure, both online and offline". In circumstances of a health crisis of vast proportions, "both the Government and the health workers closed their doors to journalists", and with this they showed their own "lack of transparency to the media and journalists" and "blocked their access to information". All this resulted in a situation where "the media have turned into mere transmitters of messages", "noncritical distribution of information without previous fact-checking" and "the journalism turned into public relations" (Table 3.2). An additional challenge for the journalists were pressures by the Government as well as pressures of a religious or a cultural nature, as the analysis of the primary data clearly indicated (Table 3.3 and Image 3.3). Access to information was the key problem that media and journalists were faced with during the pandemic. This was confirmed by the Press Council (Znachajnata uloga na sovetite za etika za vreme na Kovid-19, 2020).

When it comes to the importance of freedom of expression and receiving accurate information, especially in the time of a global crisis, it can be said that 
the extraordinary measures that each country introduces are, of course, necessary and justified. Nevertheless, questions such as "how far should those measures go?" and "how long should they be enforced?" are inevitable and legitimate. Although saving lives and protecting health are the main goals and countries need to act in a timely fashion given the circumstances, "still, their response needs to be proportional to the requests for maintaining human rights and the rule of law, which are signs of any democracy" (Mitigating a global health crisis while maintaining freedom of expression and information, n.d.), and "press freedom should not be undermined by measures to counter disinformation about COVID-19 (Mijatovic, 2020).

In addition infringements to the freedom of speech, the influx of disinformation and hate speech were the next big challenge for Macedonian journalism. All analysed media texts and publications indicated that the media space had "an incredible volume of fake news", "some media became a tool for spreading half-truths, lies and disinformation", and "the journalists were accused of spreading fake news" and were held "responsible for revealing fake news for what they are". These "models of media, groups of media and individuals that spread disinformation, propaganda and hate speech are, primarily, in the online space", "the online media are the most frequent actors in the infringement of professional standards" and "the Internet media are an especially suitable channel for spreading disinformation and encouraging hate speech" (Novinarstvoto kako javno dobro, 2020).

In regard to this influx of disinformation or an infodemic, the survey results indicated that journalists are more or less familiar with the term disinformation, but are lacking training on recognising information that has the character of disinformation and, although, for the most part, the media organisations have set guidelines on how to handle disinformation, that should not be the rule and obligation for the media. The fact that disinformation has an impact on the way journalists are reporting to the public (Image 3.5) is concerning.

The existence of disinformation is also related to the credibility of sources. According to the survey responses, journalists were consulting various sources, where the relevant ones (WHO and health experts) are mostly based on press releases, but some use of social networks was also identified. This is concerning having in mind that social media are a recognised source of disinformation, lies and half-truths (Nikodinovska, 2020).

When it comes to hate speech, the Helsinki Committee for Human Rights' monitoring indicates that there were 110 reported cases in March 2020, which is a $100 \%$ more than the same period the year before. Their analyses stress that "most of the cases were related to the emergence of the COVID-19 pandemic, proclaiming a state-wide emergency and the restrictive measures taken by the Government in March 2020". Their monitoring also shows that the online portals are channels for spreading fake news and encouraging hate speech, because for the most part their content is published on Facebook and Twitter (Govor na omraza, n.d.). 


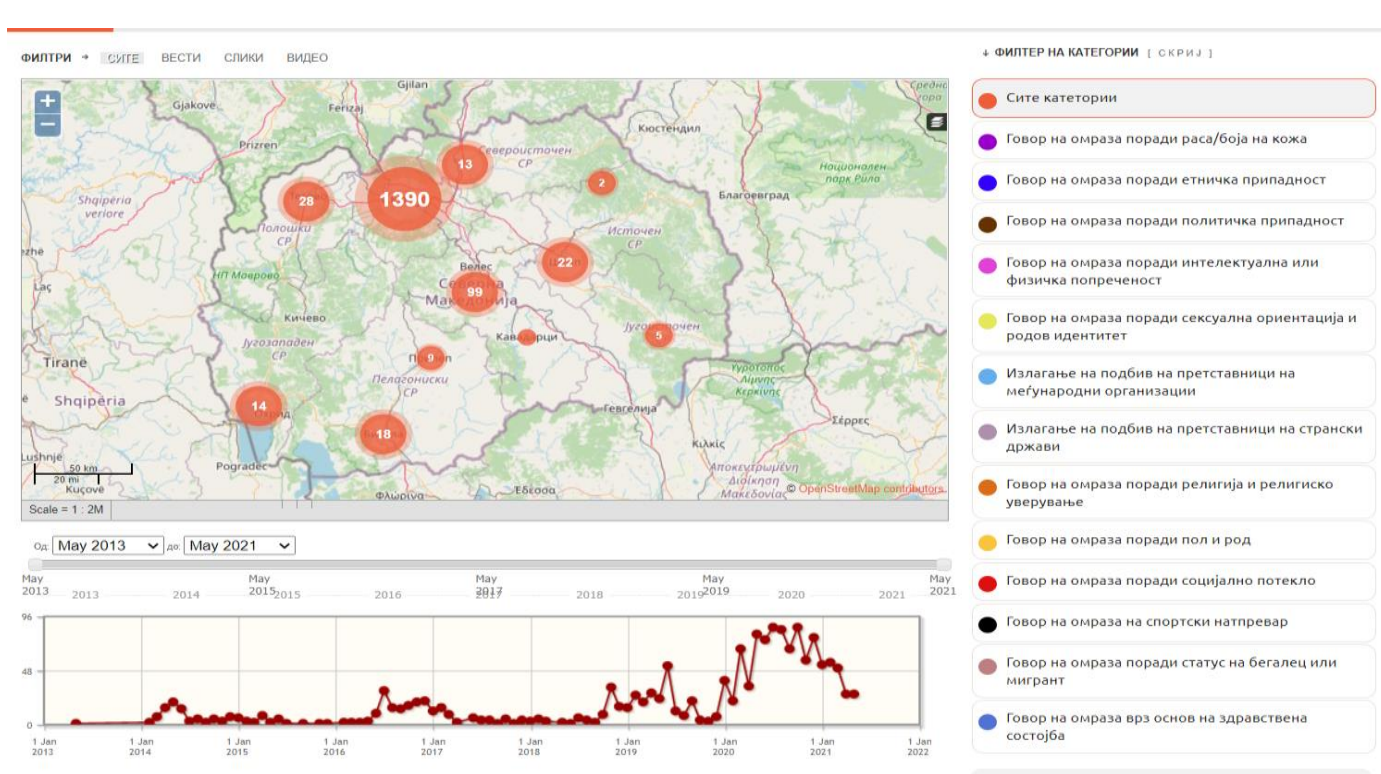

Source: Govor na omraza [Hate speech] (http://govornaomraza.mk/main).

The pandemic as a global crisis was also reflected in the economy, which inevitably made an impact on the media survival and therefore on the financial sustenance of journalists. This is a serious challenge for the journalistic profession, because good-quality and responsible journalism requires economic sustainability of media organisations. All analysed relevant texts indicated that "the media are going through an economic crisis", that "the economic and social situation of journalists and media workers is under threat" and that "there is a need for new business models in journalism" (Tuneva, 2020; ValikjNedeljkovikj, 2020). "The economic consequences from the crisis can already be felt, and according to our estimates, they will be even worse for the journalists and media workers", stated the Independent Trade Union of Journalists and Media Workers (SSNM) for PINA (Novinarite za toa kako pandemijata vlijae vrz novinarskata rabota, 2020).

The primary data also indicated that due to the nature of their profession journalists suffered deterioration in their physical and mental health, exacerbated by the possibility of exposing their closest relatives to the virus. Most of them were in a situation of being exposed to the virus, and almost every journalist stated that they know of a colleague who was infected by COVID19. The analysis of secondary data suggests that "the exposure of journalists to trauma causes long-term stress, exhaustion, anxiety, fear" and the existence of "most serious threats to journalism and journalists" is yet another challenge to their physical and mental health (Jovanovska, 2020; Gjorgjievska, 2021).

Apart from the listed challenges above, the lack of readiness and education of journalists on reporting during crises was listed as a real challenge in the relevant media texts. "The media are not ready to report during a crisis", there 
is "a lack of education among journalists on how to report during a crisis" (Znachajnata uloga na sovetite za etika za vreme na Kovid-19, 2020), and "the journalists did not find 'a secondary' credible source" (Valikj- Nedeljkovikj, 2020).

$* * *$

Freedom of expression and being informed are key pillars of a democracy and this continues to be the case during a health crisis of pandemic proportions. During a global health crisis, when human lives are literally under threat, and social isolation and social distancing is encouraged as a means of saving lives, the media have a crucial role, this time coupled with increased responsibility in providing accurate, reliable information to the public, but also in preventing the spread of panic and fostering people's understanding for and cooperation with the necessary restrictive measures and limitations. "As reaffirmed in the Council of Europe Guidelines on protecting freedom of expression and information in times of crisis, Article 10 of the European Convention on Human Rights (ETS No. 5) and the relevant case law of the European Court of Human Rights remain the fundamental standards to be applied in the exercise of those rights" (Mitigating a global health crisis while maintaining freedom of expression and information, n.d.).

***

"The lies stemming from anger and hatred spread faster and reach further than the boring facts on social media. The lie stated a million times becomes a fact. Without facts, you cannot have a truth. Without truth, there is no trust. Without all three, democracy as we know it is dead" (Ressa, 2020). 


\section{Bibliography}

Ball-Rokeach, S. J. (1985). The Origins of Individual Media-System Dependency: A Sociological Framework. Communication Research, 12, 485-510. Retrieved from https://doi.org/10.1177/009365085012004003

Caliphate shows us what performative transparency conceals. (2021, March 10). Nieman Journalism Lab. Retrieved from https://www.niemanlab.org/2021/03/caliphate-shows-us-whatperformative-transparency-conceals/

Clark, M., \& Grech, A. (2017, March). Journalists under pressure Unwarranted interference, fear and self-censorship in Europe. Council of Europe. Retrieved from https://rm.coe.int/168070ad5d

Council of Europe. (2020, July 7). The impact of the sanitary crisis on freedom of expression and media freedom. Retrieved from https://rm.coe.int/16809ef1c7

COVID-19 is hurting journalists' mental health. News outlets should help them now. (2020, July 17). Reuters Institute for the Study of Journalism. Retrieved from https://reutersinstitute.politics.ox.ac.uk/news/covid19-hurting-journalists-mental-health-news-outlets-should-help-themnow

Gjorgjievska, S. (2021, January 13). Nitu novinarite ne se imuni na pandemijata - im treba odmor, son i pomalku informacii [Journalists are also not immune to the pandemic - they need rest, sleep and less information]. Makedonski institut za mediumi [Macedonian institute for media]. Retrieved from https://mim.org.mk/mk/aktivizam/1256nitu-novinarite-ne-se-imuni-na-pandemijata-im-treba-odmor-son-ipomalku-informacii

Govor na omraza [Hate speech]. (n.d.). Helsinshki komitet za chovekovi prava [Helsinki Committee for Human Rights of the Republic of Macedonia]. Retrieved March 9, 2021 from http://govornaomraza.mk/main

Guide on Article 10 of the European Convention on Human Rights - Freedom of expression. (2021, April 30). European Court of Human Rights. Retrieved from https://echr.coe.int/Documents/Guide_Art_10_ENG.pdf

Hearn, G., \& Foth, M. (2007). Communicative ecologies: Editorial preface. Electronic Journal of Communication, 17(1-2), pp. 2-6. Retrieved from https://eprints.qut.edu.au/8171/

Houston, J. B., Thorson, E., Kim, E., \& Mantrala, M. K. (2021). COVID-19 Communication Ecology: Visualizing Communication Resource Connections During a Public Health Emergency Using Network Analysis. American Behavioral Scientist 67(7), 893-913. Retrieved from https://doi.org/10.1177/0002764221992811

How has the pandemic affected journalism? New report offers a sobering snapshot. (2020, October 13). International Journalists' Network. 
Retrieved from https://ijnet.org/en/story/how-has-pandemic-affectedjournalism-new-report-offers-sobering-snapshot

Infodemic. (n.d.). In Merriam-Webster's online dictionary (11th ed.). Retrieved June 6, 2010 from https://www.merriam-webster.com/words-atplay/words-were-watching-infodemic-meaning

Ivanovska, K., Zekhiri, A., \& Stefanov, D. (2020, June 30). Novinarstvoto za vreme na korona $i$ postkorona [Journalism during covid and postcovid]. Zdruzhenie na novinari na Makedonija [Association of Journalists of Macedonia]. Retrieved from https://znm.org.mk/novinarstvo-vo-vreme-na-korona-i-postkorona/

Jovanovska, M. (2020, May 8). Vonredna sloboda na mediumite [Emergency freedom of media]. Makedonski institut za mediumi [Macedonian institute for media]. Retrieved from https://mim.org.mk/mk/aktivizam/1186-vonredna-sloboda-namediumite

Kodeks na novinarite na Makedonija [Codex of Journalists in Macedonia]. (2015, October 15). Sovet za etika vo mediumite na Makedonija [Council for media ethics of Macedonia]. Retrieved from https://www.semm.mk/dokumenti/korisni-resursi/kodeks/91-kodeksna-novinarite-na-makedonija

Mijatovic, D. (2020). Press freedom must not be undermined by measures to counter disinformation about COVID-19. Council of Europe. Retrieved from https://www.coe.int/en/web/commissioner/-/pressfreedom-must-not-be-undermined-by-measures-to-counterdisinformation-about-covid-19

Mitigating a global health crisis while maintaining freedom of expression and information. (n.d.). Council of Europe. Retrieved April 5, 2021 from https://rm.coe.int/en-mitigating-a-global-health-crisis-whilemaintaining-freedom-of-expr/16809e2d1e

More work, less pay: COVID-19 worsens plight of stressed-out Balkan reporters. (2020, March 9). Balkan Insight. Retrieved from https://balkaninsight.com/2021/03/09/more-work-less-pay-covid-19worsens-plight-of-stressed-out-balkan-reporters/

Newman, N. (2021, January 7). Journalism, media, and technology trends and predictions 2021. Reuters Institute. Retrieved from https://reutersinstitute.politics.ox.ac.uk/journalism-media-andtechnology-trends-and-predictions-2021

Nikodinovska, V. (2020, September). Politichka $i$ ekonomska osnova na mediumskite $i$ na komunikaciskite modeli shto shirat dezinformacii $i$ govor na omraza [Political and economic basis of media and communication models spreding disinformation and hate speech]. Makedonski institut za mediumi [Macedonian institute for media]. Retrieved from https://mim.org.mk/mk/aktivizam/1186-vonrednasloboda-na-mediumite 
Novinarite za toa kako pandemijata vlijae vrz novinarskata rabota [Journalists on how the pandemic impacts their work]. (2020, May 3). Platforma za istrazhuvachko novinarstvo i analizi - PINA [Platform for investigative journalism and analysis - PIJA]. Retrieved from https://pina.mk/3297novinarite-za-toa-kako-pandemijata-vlijae-vrz-novinarskata-rabota/

Novinarstvoto kako javno dobro [Journalism as a public good]. (2020, July 13). Samostoen sindikat na novinari i mediumski rabotnici SSNM Bilten [Independent union of journalists and media workers Newsletter], 38. Retrieved from https://ssnm.org.mk/wp-content/uploads/bsk-pdfmanager/2020/07/Publikacija_Novinarstvoto_kako_javno_dobro_SS NM_br_13_juli_2020.pdf

Perreault, M. F., \& Perreault, G. P. (2021). Journalists on COVID-19 Journalism: Communication Ecology of Pandemic Reporting. American Behavioral Scientist 65(7), 976-991. Retrieved from https://journals.sagepub.com/doi/10.1177/0002764221992813

Posetti, J., Bell, E., \& Brown, P. (2020). Journalism \& The pandemic - A global snapshot of impacts. International Center for Journalists. Retrieved from https://www.icfj.org/sites/default/files/202010/Journalism\%20and\%20the\%20Pandemic\%20Project\%20Report\% 201\%202020_FINAL.pdf

Ressa, M. (2020). As democracy dies, we build a global future. Rappler. Retrieved from https://www.rappler.com/voices/thoughtleaders/analysis-as-democracy-dies-we-build-global-future

Tacchi, J., Slater, D., \& Hearn, G. (2003). Ethnographic action research, UNESCO users handbook. Retrieved from http://eprints.qut.edu.au/4399/1/4399.pdf

The UK COVID-19 news and information project. (n.d.). Reuters Institute for the Study of Journalism. Retrieved June 3, 2020, from https://www.bing.com/search?q=The+UK+COVID-

$19+$ news+and+information+project+\%7C+Reuters+Institute+for+the +Study+of+Journalism+(ox.ac.uk\&cvid=fba3caaafbf94ed4b5e7d801 4d6a227e\&aqs=edge..69i57.560j0j1\&pglt=43\&FORM=ANNTA1\&P $\mathrm{C}=\mathrm{LCTS}$

Tuneva, M. (2020, July 23). Novinarskoto izvestuvanje vo pandemijata: kade skrshnavme od patot? [Journalistic reporting during a pandemic: where did we go wrong?]. Makedonski institut za mediumi [Macedonian institute for media]. Retrieved from https://www.mim.org.mk/mk/edukacija/1220-novinarskotoizvestuvanje-vo-pandemijata-kade-skrshnavme-od-patot

Valikj-Nedeljkovikj, D. (2020, May 29). Pandemijata pokazha deka novinarite ne znaat kako da izvestuvaat vo krizni situacii [The pandemic revealed that journalists do not know how to report in times of crisis] [Blog message]. Retrieved from https://respublica.edu.mk/mk/blog/2020-0529-08-33-45

Vazhnosta na slobodata na mediumite vo vreme na pandemija [The importance of press freedom during a pandemics - News]. (2020, May 3). Council 
of Europe. Retrieved from https://www.coe.int/mk/web/skopje//importance-of-press-freedom-in-times-of-pandemics-jufrex

Wahl-Jorgensen, K. [jakelynch]. (2020, September 16). Responsible journalism in the local context: The experiences of community journalists in the coronavirus pandemic [Video file]. Retrieved from Vimeo. https://vimeo.com/458601981

World Health Organization. (2020, September 23). Managing the COVID-19 infodemic: Promoting healthy behaviours and mitigating the harm from misinformation and disinformation. Retrieved from https://www.who.int/news/item/23-09-2020-managing-the-covid-19infodemic-promoting-healthy-behaviours-and-mitigating-the-harmfrom-misinformation-and-disinformation

Znachajnata uloga na sovetite za etika za vreme na Kovid-19 [The role of press councils during the covid-19 pandemic]. (2020, October). Sovet za etika vo mediumite vo Makedonija - SEMM [Council of media ethics of Macedonia - $\quad$ SEMM]. Retrieved from https://semm.mk/dokumenti/publikacii/791-19 